\title{
THE EFFECT OF USING ENVIROMENTAL PHOTOS ON THE STUDENTS EXPOSITORY WRITING
}

\author{
by \\ Anita Kurnia Br. Zebua ${ }^{1}$ (anitakurnia911@gmail.com) \\ Vira Novriyanti ${ }^{2}$ (viranovriyanti27@gmail.com) \\ Juni Clarita Panjaitan ${ }^{3}$ (panjaitanjuni21@gmail.com) \\ Fitra Rizky Herfandy ${ }^{4}$ (fitrarizkyherfandy@gmail.com) \\ Cindy Maria Sibarani ${ }^{5}$ (cindysibarani22@gmail.com)
}

ABSTRACT-The purpose of this study is to improve the ability to write student texts through the use of media photo. This research is a class action study. Data collection done with observation. Studies indicate increased motivation for learning and the level of expository teks.

Keyword: Writting skill, Expository Writting, Photos Enviromental

\section{A. INTRODUCTION}

The basic of teaching and learning English is to make student's able to master four language skill, those are listening, speaking, reading, and Writing. But in other case writing is an important English skill that has to be learned beside the other language skill. Hartfiel, (1985) says "Writing is the primary means for conveying information, ideas, beliefs, and impressions to other when the ideas are too complex to express orally, when face to face is not possible or when a permanent form of communication is needed".

Writing begins at the time when people learn to communicative their thought and feeling in the written. It means that by writing, people can express their opinions, experience, events, and histories into a sequence of words combined into sentences in a form of paragraph in which every sentence in related one each other. Effendi (2008-327) that "writing is a language communication activity that uses language as its medium".
Writing is considered the most difficult skill since it involve several component including content, vocabularies, rhetoric, grammatical, structures, and mechanic, such as punctuation and capitalization. Setiyadi (2006:69) "Writing in the target language can be introduced shortly after language learners have begun reading. There are different types of writing, depending on the levels of language performance. They may be classified as writing or composition. There are four types of writing: imitative writing, dictation, guide writing and controlled writing".

How to start their writing the basic competency that shall be ochieved in the writing English subject is that students have abilities in developing and producing writen simple function text in the form of expository. What is expository writing? Expository is writing a text from a visible enviromental Photo and then tells its meanings or events happend. Haryono (2009:2) It explains that audiovisual media 
is a medium that has characteristics (audio) voices and visual (ficture).

Based on the background of the study, the problem of this study can be formulated as follows: "Does enviromental photos affects the student's in writting expository text?"

This study is intended to find out the effect on student's achievement in writing expository text.

Findings of this research are expected to be useful and relevant theoreticaly and practicaly:

a. Researcher, this research will gives more information and knowledge to write in expository texts using environmental photos.

b. English teacher, to apply this teaching technique to increase their students' write in expository texts.

c. Students' to give their writing skills, specifically in writing expository texts and to enlarge their knowledge about using photos environmental.

Other researchers, to increase and update their knowledge about how is the ability in writing and as the reference for further study relate to this research.

\section{B. METHOD}

Experimental research design learning to write using environmental photos with procedures consisting of expository. This sequence is everywhere through the stages experienced by various subjects so that each round is positioned by each different subject. In feeling, students take photos of the environment to be told in writing consisting of different steps in varying order. Data is taken from the same students on different tasks in the same time period. Experimental studies with completion procedures are divided into several groups. The aim is to measure students' abilities in several groups.

Data collection is divided into two times. The first activity will be done at the Sinar Husni Junior High School, to do a data of pre test before writing carried out on the month06 Mei 2019. Second, students are assigned to treatment is application of the media giving audio visual or photos on the month 15 Mei 2019, post test is giving exercise media audio visual write expository text using enviromental photos out on month 28 Mei 2019. Finally analysis and evaluation for finding result on month 12 July 2019. The researcherusing an photos enviromental as research materials.

Pre-test will be given to students before experiment begins. The observation test is aimed to find writing skill and analyze of English in students in seeing in object to photos expository. The preparation that must be done by the teacher before testing students is to look at student attitudes, student attendance, and students' ability to talk and think in everyday.Pretest is done by displaying a ward photo, then students are directed to explain what they see and write it down on a piece of paper.

The treatment is divided into two times. First, students will be taught how to explain images from the side they see, from this photos of the enviroment, they will be taught to assemble words that describe the beautiful of the environment. Second,students are assigned to make a grouping before starting to write.Studentswill be given the task of writing down what they see from photos expository of the ward using grouping. In this case, the two subjects were given an 
opportunity of about 90 minutes. To do a test consisting of: Writing concepts, observing and editing. The subject of this study focuses on writing, which usesphotos watching technique.

For this postest students will be divided into groups, make a group of five person. The group will be given a photos of the ward according to each group's choices. The time to do so will be given 50 minutes. This will be able to judge which groups are most enthusiastic about explaining the enviromental photos that they are working on. Jugment will be renderedat speed, appealing and of great significance. This research will be carried out at one of the Junior High School, which consists of Junior High School only grade 2 . In this case the researcher took class a students as research samples.

\section{RESULT AND DISCUSSION}

1. The use of photos expository environmental for second grade students SMP Sinar Husni

Class action research by applying photos media to English subjects. The implementation of the learning with environmental utilization as a learning resource to improve the writing skills of the description consists of several stages, namely, the planning steps, the execution stage, the observation stage, and the reflection stage. In the planning phase, preparing media photos and organizing research instruments. In addition to the planning phase, it then follows the execution and observation phase. Observation, at this stage to know the process of study done and student activity in the learning activity using the research abservation sheet and which is the object of a research observation.
Cognitive research data is for students, and aspect indicators of the learning activities are consistent with the observation instrument. Aspects of the teacher's learning process include planning, key activities, and impalement. This stimulus and response relationship, if repeated can become a habit.

Reflections are carried to know the inadequacy or constraint of cycle I. The implementation on cycle 1 was quite good, but there were some obstacles. The problem is that students are still less active in expressing opinion and less answering question, students still pay little attention to the lesson while the teacher is explaining. To achieve this level of improvement, effective measure must be taken so that the learning result of cycle II can be more optimal. Efforts to create the ability of learners to achieve educational goals require an improvement in teachers' performance as teachers. The learning activities that will be performed in cycle II how to teach to the weaknesses that occur in cycle I.

\section{The motivation for learning can be enhanced with the use of environmental photos media}

Learning activities are carried out aimed at improving the students' learning success after experiencing the learning process. One that is done to achieve the success of learning to be effective and efficient, is to use study methods that correspond to the material taught. Teaching English subject especially to using environmental based photos media application of improving expository writing ability is needed by methods that help students to grasp concepts and publications properly. Therefore, the use of image media is expected to bring more 
knowledge and understanding to students through firsthand use of the media is a method of providing opportunity to individual students or groups to be trained to do a verification of the truth in pictures. With the application of the teaching media will be more effective.

Based on the research conducted at the SMP Sinar Husni Helvetia in learning to write expository texts using the medium of environmental photos took a boost. Studies appear that the use of the environmental media photos has had an influence in improving expository writing skills for class 2 grade. Analysis results simply support the proposed theory that learning media in prosea learning can awaken new desires and interests, stimulating motivation and stimulation of learning activities, and even having a psychological influence on students. The use of learning media at the learning orientation stage is helpful to the effectiveness of the learning process and transmission and content of the lesson at the time. In addition to stimulating students' interests and motivations, the leraning media can also help students increase understanding, acquire interesting and reliable data, facilitate data interpretation, and obtain information (Ashar Arsyat 2013: 19).

The environmental cultural based media application have a positive influence on student prosea learning in writing expository, as student are better able to understand the material by using environmental based media, and student are more about expressing themselves towards the environment. Developing info imaging skills is an attempt to improve the ability to write expository of students who are the precursor of English studies.In the learning process teachers must have methods that vary in English lessons, especially discussions teach students using the enviromental photos (Visual) media, introducing the media photos at once, in English and so on.

\section{CONCLUSION AND SUGGESTION}

Based on studies obtained and analyzed, it may be concluded that the use of photos media can improve expository writing skills. This can be seen from the enthusiasm of the students in the learning process and the making of the expository. With the use of environmental photos media in the student learning process becoming more active, could put the ideas down well, write in the right writing code, and be more enthusiastic about following the laerning.

Photos are two dimensional visual medium over a non transparent field. The teacher may use photos to illustrate the lessons discussed so that the explanation is more concrete than they are described by words

\section{REFERENCES}

Piazza, C. L. (2003). Journeys: The teaching of writing in elementary classrooms. (22-28)

Mitchell, J. (2003). On-line writing: A link to learning in a teacher education program, 19, 127-143.

Blasingame, J., \& Bushman, J. H. (2005). Teaching writing in middle and secondary schools. Saddle River, NJ: Pearson. 
Bahasa Indonesia Prima, Vol 2, No. 1, 2020

e-ISSN: 2684-6780

Cifuentes, L., \& Hughey, J. (2003). The interactive effects of computer conferencing and multiple intelligences on expository writing. The Quarterly Review of Distance Education, 4(1), 15-30.

Piazza, C. L. (2003). Journeys: The teaching of writing in elementary classrooms. Upper Saddle River, NJ: Merrill Prentice Hall.

Novita, V. T.2014.The Effectiveness Of Teaching Writing Through Picture Series To Grade VIII Students Of SMP $N 3$ Sleman. Yogyakarta University. Yogyakarta

Siahaan, J. 2013. An Analysis Of Students' Ability And Difficulties In Writing Descriptive Text. Indonesia University. Jakarta. 